\title{
EFFECT OF DRYING METHODS ON CHEMICAL COMPOSITION AND SENSORY PROPERTIES OF AMRY DATE
} Ibrahim, A.A.; M.G. Abd El Fadeel: S.I. Ghoneim and F.A. Abd El Razicl Department of Food and Dairy Science and Technology.Faculty of Environmental Agricultural Sciences.Suez Canal University.

\section{ABSTRACT}

In many countries of the world the use of sun drying in agricultural area to conserve vegetable, fruits and other crops has shown to be practical economically and the responsible approach environmentally .In this investigation we used sun drying, oven drying (at $60^{\circ} \mathrm{C}$ and $90^{\circ} \mathrm{C}$ ) and greenhouse drying to dry date of Amry variety grown in North Sinai . The chemical composition and sensory properties were studied. Results showed that the moisture ,tannin ,total acidity and crude fiber were decreased after drying methods, while pectin , color, ash and total and reducing sugar were increased. Results showed that the greenhouse drying was the best method of drying for Amry date, while the oven drying at $90 \mathrm{C}^{\circ}$ resulted in the lowest quality of products.

\section{INTRODUCTION}

Date is an important commercial crop in Middle East and Arab countries. Egypt lies in the first largest date producer among Arab and world countries (FAO 2004).North Sinai region is one of the most important date cultivated areas in Egypt, where the cultivated date variey is Amry dates (semi dry dates) which spread in Beir El-Abed city.Date fruit is a rich source of carbohydrates comprising mainly for sugar and dietary fiber, making it one of the most nourishing natural foods available to the man Kulkarni ,et al (2007)

The different varieties of date produced in Egypt are firstly the soft varieties such as Hayany ,Amhat ,Zaghloul,Samany and Bent Aisha, Nezam EIDin , (2000) , secondly the semi dry varieties of dates such as Amry ,Aglany and Sewi. Then the dry varieties of dates such as Sakoty and Gandila.

Dates at rutab stage are rich in sugars with high moisture content and are easy to bruise during handling, unless it is readily consumed, they are highly susceptible to yeasts fermentation and therefore its shelf life is low. Bekheit, (2002)

Drying becomes necessary when dates contain high moisture content and will not be consumed immediately or stored under refrigeration. Drying of soft dates at $65^{\circ} \mathrm{C}$ was recommended by Barraveld, ( 1994)

Date producers usually dry the date by traditional sun drying method which suffers of some hazards such as dust storms, rains, insects and rodents and the obtained products are solid and difficult-to-use.

This investigation was amid to study the effect of different drying methods of Amry dates on chemical composition and sensory properties to 
select the appropriate drying method for Amry dates and improve the quality of products.

\section{MATERIALS AND METHODS}

\section{Materials}

Amry dates variety (semi dry dates) at Khalal stage were obtained from Beir El-Abed city (North Sinai Governorate ) from local market.

\section{Methods}

\section{1- Drying process.}

Amry dates variety (semi dry dates) at Khalal stage were divided into four parts. The first part was dried in sun drying (traditional method) and turned off every day and covering nightly for 15 days. The second part was dried in oven at $60^{\circ} \mathrm{C}$ for $24 \mathrm{hr}$. The third part was dried in greenhouse on wooden trays $(75+150 \mathrm{Cm})$ for 10 days, it was turned off every day. The fourth part was dried in oven at $90^{\circ} \mathrm{C}$ for $5 \mathrm{hr}$ and the all products were packaged in polyethylene bags.

\section{2- Analyses methods}

2.1 Gross chemical composition

The moisture ,ash, fiber contents and total acidity of fresh and processed dates and during dehydration of processed dates were determined according to the method described in A.O.A.C. (1990). The results for acidity were calculated as malic acid in fresh date samples and date products

\section{Pectin content:}

Soluble pectin content of fresh and processed date samples was determined according to the method described by Lees (1975):

Tannins content:

Tannins were determined according to the procedure described by Ranganna (1977):

\subsection{Color intensity:}

Color intensity of alcohol extracts of fresh and processed date samples was determined according to the method of Ranganna (1977)

\section{Organoleptic evaluation:}

Date products were organoleptically evaluated for its taste, color, texture and odor according to the method of Sumainah, (1984) and Yousif (1990). by ten panelists using a numerical basis of one to ten (where one $=$ very bad and $10=$ excellent).

\section{Statistical analysis:}

The obtained data of the organoleptic evaluation were statistically analyzed according to Snedecor and Cochran (1980)

\section{RESULTS AND DISCUSSION}

\section{Gross chemical compositions of Amry tamr dates}

Regards to the moisture content which considered the most important factor, that controls and regulates the deterioration of sensitive quality attributes in the dried fruits. The main purpose of drying is to reduce 
the moisture content to a level that can prevent growth of microorganisms and food spoilage. Bekheit ,(2002). The chemical composition of Amry dates after drying by different methods was presented in Table (1)

Data in Table (1) show that the moisture content of fresh Amry date. sample was $53.6 \%$, while $11,21,18 \%$ and $16.2 \%$ in dates dried using drying methods manely sun, green- house, oven at $60^{\circ} \mathrm{C}$ and oven at $90^{\circ} \mathrm{C}$, respectively. The moisture decrease recorded the highest decrease in sun drying while the lowest decrease was noticed in greenhouse treatment for Amry date. These results were accordance with those of Kulkarni et al (2007) who reported that the final moisture content of immature dates(Phoenix dactylifera L.) was ranged from 15 to $16 \%$. Al-Shahib and Marshall,(2002) found that moisture contents were mostly between $11 \%$ and $36 \%$, in different dates

Table (1): The effect of drying methods on some chemical constituents of Amry date products

\begin{tabular}{|c|c|c|c|c|c|c|c|}
\hline Treatments & Moisture & Ash & $\begin{array}{c}\text { Crude } \\
\text { fiber }\end{array}$ & Pectin & $\begin{array}{c}\text { O.D.at } \\
\text { 420nm }\end{array}$ & Acidity & Tannin \\
\hline Fresh & 53.6 & 1.5 & 3.6 & 2.3 & 0.115 & 0.28 & 0.8 \\
\hline Sun drying & 11 & 2.0 & 3 & 4 & 0.165 & 0.30 & 0.45 \\
\hline Greenhouse drying & 21 & 2.0 & 3.1 & 4 & 0.194 & 0.25 & 0.44 \\
\hline Oven drying at $60^{\circ} \mathrm{C}$ & 18 & 1.7 & 2.6 & 4 & 0.184 & 0.20 & 0.47 \\
\hline Oven drying at $90^{\circ} \mathrm{C}$ & 16.2 & 1.6 & 3.3 & 3.1 & 0.186 & 0.11 & 0.47 \\
\hline
\end{tabular}

Concerning to the ash content, results in the same Table show that the ash content of fresh Amry was $1.5 \%$. Also, the ash content was increased after drying by different methods, where the lowest increasing in the ash content was recorded when oven drying at $90^{\circ} \mathrm{C}$ was used $1.6 \%$ followed by, oven drying at $60{ }^{\circ} \mathrm{C} 1.7 \%$ and greenhouse and sun drying $2.0 \%$. These results are in agreement with those of EL-Ghazali and Hussin (1999), who reported that the ash content of Gondaila date increased after sun and mechanical drying Vandrook, et al (1979),who reported that the ash in dried dates $1.9 \%$

Concerning to the crud fiber content, results in the same Table show that the crude fiber content of fresh Amry date was 3.6\% . Also crud fiber content decreased after drying by different methods, where the highest decreasing in the crud fiber content was recorded when oven drying at $60^{\circ} \mathrm{C}$ was used $1.0 \%$ followed by, sun drying 0.6 , greenhouse drying $0.5 \%$ and oven drying at $90{ }^{\circ} \mathrm{C} \quad 0.3 \%$. These results are in agreement with those of Vandrook, et al (1979), who reported that the total fiber in dried dates was 2.3 $\%$.

Concerning to the pectin content results in same Table and show that the pectin content of fresh Amry date was 2.3\%. Results obviously show pectin contents of dates in all treatments were increased after drying 3.1-4 $\%$ compared with fresh (2.3\%). These results are in agreement with those of Bekheit , (2002), who reported that the pectin content increased after dehydration from 2.7 to 3.2 in date sheets. 
Results in the same Table indicate that the color intensity (absorbance at $420 \mathrm{~nm}$ ) of Amry date after drying was $0.152 \%$. The optical density increased after using the different methods of drying in Amry date fresh sample. This increment was ranged from 0.115 to 0.186 These results were agreed with those of Bekheit (2002) who, noticed that there was an increase in darkening of date sheets compared to date fruit when make the sheets by dehydration . This may be due to the reaction between reducing sugars and amino acids or organic acids during dehydration

Data mentioned in Table (1) indicated that the total acidity (as malic acid) of Amry date fresh sample was $0.28 \%$ ( on dry weight basis), which slightly decreased by using other different drying treatments in the rang of 0 . $25-0.1 \%$ except sun drying $(0.30 \%)$. These findings are agreed with Nezam El Din (1996), who found that total acidity of Bent Aisha date (soft date) was decreased from to $0.33 \%$ in khalal stage $0.30 \%$ after drying and Abougou, (1980), who reported that the decrease in acidity may be due to the effect of higher temperatures on evaporation of volatile organic acids .

The presented results in Table (1) show that the total tannin in fresh Amry date sample was $(0.8 \%)$ ( on dry weight basis). Results are demonstrated also samples of all treatments were decreased in tannin content $0.44-0.47 \%$, after drying .These results was in harmony with those of .Nezam El-Din and Abd-El-hameed (1997) .and Sawaya et al., (1983) They reported that the tannin content at khalal stage was 1.2 to $6.7 \%$, decreasing to 0.6 to $3.2 \%$ at the tamar stage.

\section{Sugars content}

Sugars, are considered the most important constituents in determining the quality of the dried fruits. .

Results in Table (2) indicate that the total sugar and reducing sugar were $49 \%$ and $42 \%$ in fresh Amry date respectively. This results was similar with Kulkarni (2007) studied the effect of dehydration on quality and storage stability of immature date (phoenix dactylifera) and reported that the total sugar $52 \%$ and reducing sugar of $41 \%$. The total and reducing sugar increased after drying treatments ranged from (68.2-81\%) (42-70.2\%). respectively, These results are in agreement with those of EL-Ghazali and Hussin (1999), who reported that the total and reducing sugars increased after sun and mechanical drying in Bartamuda and Gondaila dates. Rizk,and Omima (2004) found that the total and reducing sugars in Sewy date (semi dry) were 78.5 and $51.4 \%$, respectively .

Table (2): The effect of drying methods on total and reducing sugar content of Amry date

\begin{tabular}{|c|c|c|c|}
\hline Drying methods & Total sugar & Red. sugar & n. red. sugar \\
\hline Fresh & 49 & 42. & $7 \%$ \\
\hline Sun drying & 68.2 & 58 & $10.2 \%$ \\
\hline Oven drying at $60^{\circ} \mathrm{C}$ & 80 & 54 & $26 \%$ \\
\hline Greenhouse & 81 & 70.2 & $11.1 \%$ \\
\hline Oven drying at $90^{\circ} \mathrm{C}$ & 68.4 & 42.2 & $26.4 \%$ \\
\hline
\end{tabular}


Results in the same Table show that the total sugar and reducing sugar increased in all treatments after drying compared with those of fresh date fruit .These results were in agreement with those of Nezam El - Din (1997), who found that the total and reducing sugar in (Amhat variety) were increased by increasing the temperature from $40^{\circ} \mathrm{C}$ to $70^{\circ} \mathrm{C}$ while it decreased at $80^{\circ} \mathrm{C}$.

Nezam El - Din (1996) found that the total and reducing sugar in (Bent Aisha Varity ) were increased after drying compared with fresh date. Also results in the same Table showed that the the greenhouse treatment was the highest value in total sugar and reducing sugar after drying than that the other treatments. Also results in the same Table showed that the oven drying at $60^{\circ} \mathrm{C}$ and $90^{\circ} \mathrm{C}$ were the lowest value in reducing sugar it may due to the effect the heat temperature on browning reactions (Abougou, 1980).

\section{Evaluation of air drying process of Amry date}

Moisture content expressed as a moisture ratio $\left(\mathrm{kg} \mathrm{H}_{2} \mathrm{O} / \mathrm{kg}\right.$ dry matter) was determined and followed up to different time intervals during the entire drying.

Drying Amry date at khalal stage were prepared by washing before loding in the drier cabinet, as described before process.

Table (3): The relationship between moisture content (M.C.) and time during oven drying for Amry date( khalal stage ) at $60^{\circ} \mathrm{C}$ and $70^{\circ} \mathrm{C}$.

\begin{tabular}{|c|c|c|c|c|c|c|}
\hline $\begin{array}{c}\text { Time } \\
(\mathrm{min})\end{array}$ & $\begin{array}{c}\text { Weight of } \\
\text { sample(g) } \\
\text { at 60 }{ }^{\circ} \mathrm{C}\end{array}$ & $\begin{array}{c}\text { Weight of } \\
\text { moisture } \\
(\mathrm{g})\end{array}$ & M.R. & $\begin{array}{c}\text { Weight of } \\
\text { sample(g) } \\
\text { at 70 }{ }^{\circ} \mathrm{C}\end{array}$ & $\begin{array}{c}\text { Weight of } \\
\text { moisture } \\
(\mathrm{g})\end{array}$ & M.R. \\
\hline 0 & $5475 \mathrm{~g}$ & 29.02 & 1.128 & $5480 \mathrm{~g}$ & 29.04 & 1.127 \\
\hline 60 & 5436 & 28.63 & 1.113 & 5363 & 27.87 & 1.083 \\
\hline 120 & 5362 & 27.89 & 1.084 & 5258 & 27.82 & 1.080 \\
\hline 180 & 5287 & 27.14 & 1.055 & 5135 & 26.59 & 1.032 \\
\hline 240 & 5216 & 26.43 & 1.027 & 5010 & 25.34 & 0.984 \\
\hline 300 & 5149 & 25.76 & 1.001 & 4891 & 24.15 & 0.938 \\
\hline 360 & 5089 & 25.16 & 0.978 & 4792 & 23.16 & 0.900 \\
\hline 420 & 5015 & 24.42 & 0.949 & 4703 & 22.27 & 0.865 \\
\hline 480 & 4930 & 23.57 & 0.916 & 4618 & 21.42 & 0.832 \\
\hline 540 & 48.69 & 22.96 & 0.892 & 4556 & 20.80 & 0.807 \\
\hline 600 & 4808 & 22.35 & 0.869 & 4488 & 20.12 & 0.781 \\
\hline 660 & 4733 & 21.6 & 0.839 & 4402 & 19.26 & 0.748 \\
\hline 720 & 4690 & 21.17 & 0.823 & 4360 & 18.84 & 0.731 \\
\hline 780 & 4643 & 20.7 & 0.805 & 4312 & 18.36 & 0.713 \\
\hline 840 & 4597 & 20.24 & 0.787 & 4274 & 17.98 & 0.698 \\
\hline 900 & 4556 & 19.83 & 0.771 & 4237 & 17.61 & 0.684 \\
\hline 960 & 4515 & 18.74 & 0.728 & 4210 & 17.34 & 0.673 \\
\hline 1020 & 4496 & 18.55 & 0.721 & 4192 & 17.16 & 0.666 \\
\hline 1080 & 4461 & 18.2 & 0.707 & 4170 & 16.94 & 0.658 \\
\hline 1140 & 4426 & 17.85 & 0.694 & 4152 & 16.76 & 0.651 \\
\hline
\end{tabular}




\section{Drying mechanism:}

As seen in Figs (1), drying curve was characterized by two phases of different drying mechanism. The first phase was a short time phase of 180 min from the beginning of drying and was characterized by a linear relationship between drying time and change in moisture content it is called constant rate drying phase. This phase starts with the initial moisture content (Mi) of the fruits and ends at the critical moisture content (Mc). The initial moisture content was almost equal for all treatments, while the critical moisture content varied with the variation in the drying temperatures. The second phase starts at the critical moisture content and last until the dried fruits has achieved the final moisture content. In this phase, the rate of moisture removal decreased with the progress of the drying time. This phase called the falling rate drying phase. The drying time during this phase depends on the available moisture content and the drying temperature by which the moisture move from inside the fruit towards the surface which, in turn, depends on the varieties of the dates.

The parameters of the constant drying phase could be estimated by the change in drying rate was plated against the change in moisture content, as presented in Figs (2). The curve consists of two or three parts, horizontal part representing the value of the constant rate of drying. A second part with a negative slope representing the change in drying rate with change in residual moisture content during the falling period of drying time. The third part, if present, represent the second falling rate of drying .From Fig (2) it could be observed, that the values and the stages of constant and falling drying rate of Amry dates depend on the drying temperatures .Drying temperature at $70^{\circ} \mathrm{C}$ of Amry date resulted in higher values of constant rate of drying $\mathrm{kg} \mathrm{H} 2 \mathrm{o} / \mathrm{kg} \mathrm{D} \mathrm{M}$. hr. ). Such treatments gave a one curve and one stage of the falling rate period.

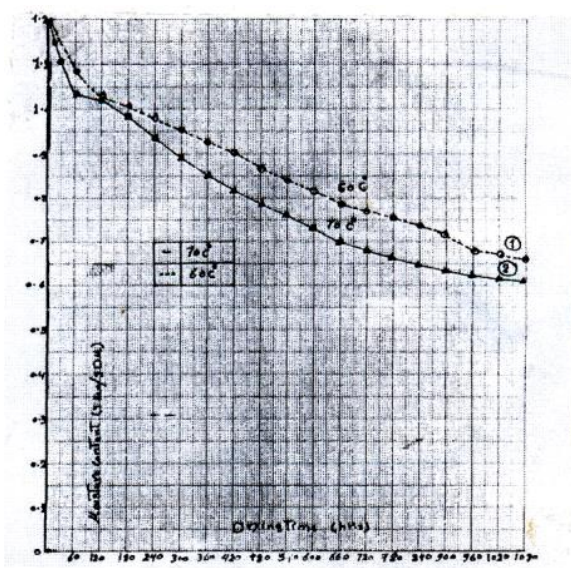

Fig (6) Drying curve of Amry date dried in electrical heated forced air oven at $60 \mathrm{C}^{\circ}$ and $70 \mathrm{C}^{\circ}$

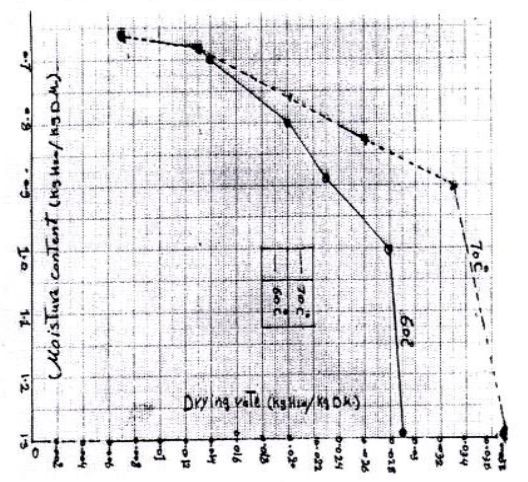

Fig (7) Drying rate curve of Amry date dried in electrical heated forced air oven at $60 \mathrm{C}^{\circ}$ and $70 \mathrm{C}^{\circ}$ 


\section{Sensory properties}

The quality and nutritive value of dates are influenced by their chemical composition ( Vandercook et al 1979 ) . Dates contain essential nutrients, high sugar content as well as moderate percentages of minerals, protein ,lipids and vitamins. Moreover, dates have high caloric, nutritive values , and medical value (Youssef and Ramadan 1987: Ramadan 1990 )

Amry date products (treated samples) were sensory evaluated for, taste, color, texture and odor, (scores 10 degree) and the results were statistically analyzed and recorded in Table (4).

From the tabulated results, it could be noticed that, greenhouse drying recorded the highest taste score (8.45), which significantly different from the other methods, with the exception of oven drying at $60^{\circ} \mathrm{C}(8.04)$. Oven drying at $90^{\circ} \mathrm{C}$ had the highest effect on baste color comparing to the other drying methods this may be due to the effect of high temperature on inducing the pigment oxidation of the date and carotene degradation and then recorded minimum value (6.20) .

The oven drying at $60^{\circ} \mathrm{C}$ had the best effect on in texture (8.41), which dose not significantly different from the other treatments, with the exception of oven drying at $90^{\circ} \mathrm{C}(6.5)$. The greenhouse drying recorded the highest odor value (8.50) which had no significant differences comparing to the other treatments, with the only exception was noticed for of oven drying at $90^{\circ} \mathrm{C}(6.75)$.

From the results in Table (4) it could be concluded that the products of Amry date dried using greenhouse and oven drying at $60^{\circ} \mathrm{C}$ had slightly higher sensory quality, where the total average of recorded scores of taste ,color, texture and odor were (8.50 and 8.29)followed by sun drying (7.9), oven drying at $90^{\circ} \mathrm{C}(6.4)$ respectively

Table (4) Sensory properties for Amry products

\begin{tabular}{|c|c|c|c|c|c|}
\hline Treatments & S.D. & $\mathbf{O ~ . D ~ a t ~} \mathbf{6 0}^{\circ} \mathbf{C}$ & G.H.D & O.D.at $\mathbf{9 0}^{\circ} \mathbf{C}$ & L.S.D \\
\hline Taste & $7.333 \mathrm{~b}$ & $8.0417 \mathrm{ab}$ & $8.4583 \mathrm{a}$ & $6.2083 \mathrm{c}$ & 1.0803 \\
\hline Color & $8.3750 \mathrm{a}$ & $8.4167 \mathrm{a}$ & $8.5417 \mathrm{a}$ & $6.2083 \mathrm{~b}$ & 0.6317 \\
\hline Texture & $7.9167 \mathrm{a}$ & $8.4167 \mathrm{a}$ & $8.2500 \mathrm{a}$ & $6.5417 \mathrm{~b}$ & 0.7826 \\
\hline Odor & $8.1250 \mathrm{a}$ & $8.2917 \mathrm{a}$ & $8.5000 \mathrm{a}$ & $6.7500 \mathrm{~b}$ & 0.9409 \\
\hline Total average & 7.9 & 8.2 & 8.5 & 6.4 & 0.8588 \\
\hline
\end{tabular}

sun drying on pepper

$O$.D at $60^{\circ} \mathrm{C}$------- oven drying at $60^{\circ} \mathrm{C}$

G.H.D -

O.D.at $90^{\circ} \mathrm{C}$---oven drying at $90^{\circ} \mathrm{C}$ 


\section{REFERENCES}

A.O.A.C. (1990) Official Methods of Analysis of the Association of official Analytical Chemists. Published by the Association of Official Analytical Chemests Inc. Arlington, Virginia, 2209 U.S.A.

Abougou, J.C. (1980). Nutritional evaluation of osmotic and non osmotic greenhouse dehydrated peaches. M.Sc. Thesis, in the graduate college,Arizona Univ.,USA

Al-Shahib, W.and Marshall, R.J.( 2002). Dietary fibre content of dates from 13 varieties of date palm Phoenix dactylifera L. International Journal of Food Science and Technology. 37(6): 719-721

Barreveld, W.H. (1994). Date palm products. Food and Agriculture Organization of the United Nations Agricultural Services Bulletin No. 101. Rome.

Bekheit A.A.(2002 ) Production and evaluation of Egyptian date sheets and pastes Ph.D. Thesis Food Sci.and Tech. Dept., Fac. of Agric.,Cairo Univ.,Egypt

EL Ghazali . M.N. and F. Hussin (1999) . Effect of sun drying and mechanical drying on composition and libid, phospholipids fractions of Aswan dry dates. Egypt J. Hort. 2,(2) 209-215

F.A.O. (2004) Production year book, Food and Agriculture Organization of United Nations.Bulletin of Statistics, volume (1),No 2

Kulkarni S.G., Vijayanand .P A.M., Reena, P. and Ramana, K.V.R.(2007) Effect of dehydration on quality and storage stability of immature dates ( Pheonix dactlifera). Food Sci. and Technology.Proceedings of the regional workshop on date palm Post-harvest processing technology Tehran, Iran, 11-14, October 1999.drying of soft date (Bent- Aisha variety). Egypt J. Agric. Res., 74 (3): 821-833.

Lees, R. (1975). Food analysis: "Analytical and quality control methods for the food manufacturer." 3rd Ed., Published by Lenoard Hill Books, London, England

Nezam El-Din, M. A. (1996). Effect of some technological treatments on ripening and drying of soft date (Bent- Aisha variety). Egypt J. Agric. Res., 74 (3): 821-833.

Nezam El-Din,A.M.(2000).Date palm post-harvest processing technology in Egypt. Proceedings of the regional workshop on date palm Post-harvest processing technology Tehran, Iran, 11-14, October 1999.

Nezam El-Din, M. A. and Abd El-Hameed, A.K. (1997) Chemical and technological study on Egyptian Amhat date.2-Drying of Egyptian Amhat date. Egypt J. Agric. Res., 75 (4): $1154-1160$. 
Ramadan,R.B. (1990) .Chemical And Technologcal Studies on some New Vally Dates M.S.C. Thesis food Sci.and Tech. Dept., Fac. Of Assiut

Ranganna, S. (1977). "Manual of analysis of fruit and vegetable products". Tata Mc Graw-Hill Publishing Co. Limited, New Delhi

Rizk,S.A. and Omima, M. ELSayed(2004) Evaluation of some date palm cultivars grown under El Bahria Oasis Egypt Egyptian J. Desert Res. 54,(1), 169175

Sawaya,W.N.; Safi, W.M.and AI-Muhammad,-M-M. 1983a. Physical and chemical characterisation of the major date varieties grown in Saudi Arabia. II. Sugars, tannins, vitamins A and C. Date Palm Journal. 2(2): 183-196

Snedecor,G.W. and Cochran, W.G. ( 1980) Statistical methods . 17 Education lowa State Univ. Press Ames, lowa U.S.A

Sumainah.G.M. and EL-Nahal,H.(1984)Tamr-Eddin Anew product of date. J.Fd.Sci. Tech., 21, 88-91

Vandrook,C. E., Hasegawa. S.and Maier V.P. (1979)Quality and nutritive value of dates as influenced by their chemical composition. Date Grower,s I NST. Rep. 54; 3-11

Yousif,A.K,AbouAli, M. and Bouldreese,A.(1990) Processing ,evaluation and storability of date . J. F. Sci.Tech. 27 (5) 264-267-97-

Youssef, A.K. and Ramadan ( 1987)Nutritive value of Dates .Technical Bull. No. 15, September, Fac. Of Agric. Assiut Univ. Egept.

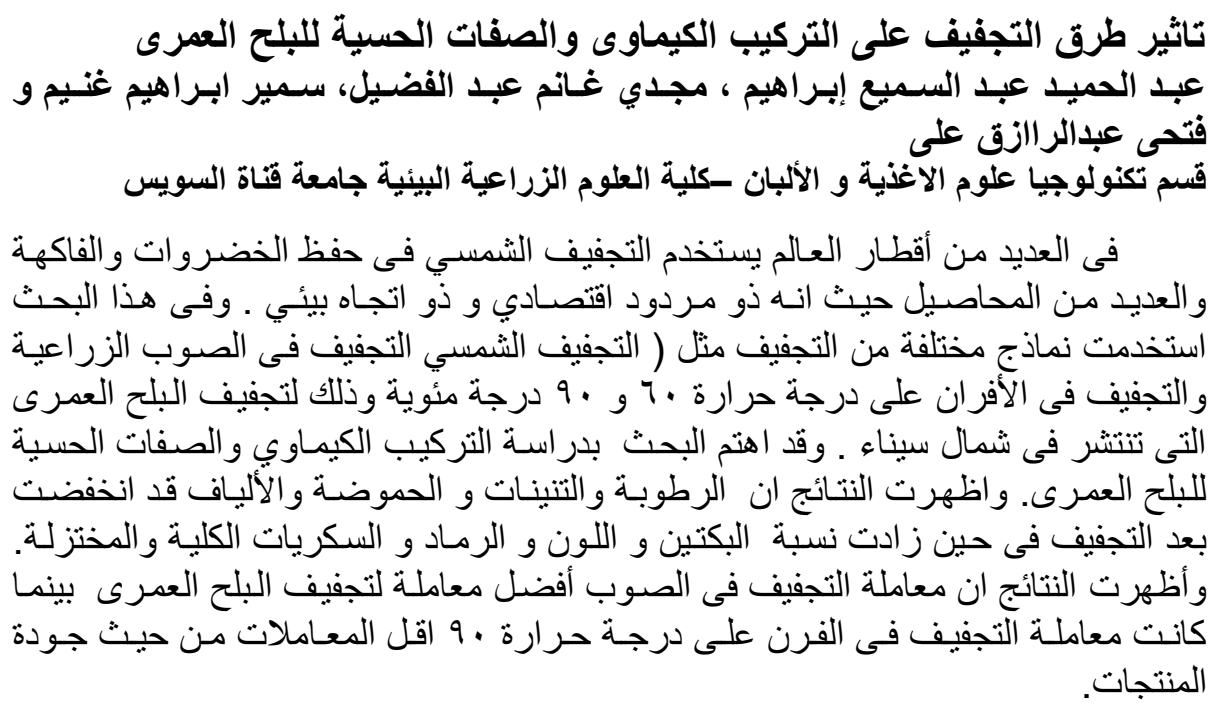

